\title{
Penicillinase-producing Neisseria gonorrhoeae in Riyadh, Saudi Arabia
}

\author{
M N H CHOWDHURY, S S PAREEK, AND EL-SHEIKH MAHGOUB \\ From the Department of Microbiology, Faculty of Medicine, Riyadh University, Riyadh, Saudi Arabia
}

SUMMARY Of 83 strains of Neisseria gonorrhoeae isolated in Riyadh, Saudi Arabia, between April 1979 and August 1980, 10 produced $\beta$-lactamase and had minimum inhibitory concentrations (MICs) of penicillin between 1 and $\geqslant 4 \mu \mathrm{g} / \mathrm{ml}$. Of the $73(88 \%)$ non-penicillinaseproducing strains, $55 \%$ had diminished sensitivity to penicillin (MIC $=0.06 \mu \mathrm{g} / \mathrm{ml}$ ) and $11(15 \%)$. were highly resistant (MICs ranging from $0 \cdot 5-2 \mu \mathrm{g} / \mathrm{ml}$ ). This high incidence of resistance may be due to widespread abuse of antibiotics; it also confirms that two mechanisms of resistance to $\mathrm{G}$ penicillin exist in this species.

\section{Introduction}

Relative resistance of Neisseria gonorrhoeae to penicillin has been reported from all over the world. ${ }^{12}$ Although penicillin still remains the drug of choice in the treatment of gonorrhoea, treatment failures are becoming more common. Recently, the problem of antibiotic resistance in strains of $N$ gonorrhoeae has been aggravated by the appearance of penicillinase-producing strains (PPNG). The first two PPNG strains were isolated in the USA in $1976,{ }^{34}$ and at the end of the same year a national surveillance programme was initiated to detect infections due to PPNG in the USA. In 1977, 191 cases of PPNG infection were confirmed at the Center for Disease Control (Atlanta, Georgia, USA). ${ }^{5}$ PPNG strains were also isolated for the first time in Britain in 1976; most of these reports were of single sporadic cases. ${ }^{6} 7$ There was, however, an outbreak of gonorrhoea due to PPNG strains in $\mathbf{7 6}$ patients in Liverpool, England, between February and November of that year. ${ }^{8}$ Since then, there have been several reports on their appearance in South Africa, ${ }^{9}$ some parts of the USA, ${ }^{10}$ Singapore, ${ }^{11}$ Hong Kong, ${ }^{12}$ West Germany, ${ }^{13}$ and the Netherlands. ${ }^{14} 15$

As far as we know there are no published data on the incidence of strains of $\mathbf{N g o n o r r h o e a e}$ resistant to penicillin in Saudi Arabia. We have, therefore, studied the penicillin sensitivity and $\beta$-lactamase production of strains of $N$ gonorrhoeae isolated in

Address for reprints: Professor El-Sheikh Mahgoub, Department of Microbiology, Faculty of Medicine, Riyadh University, PO Box 2925, Riyadh, Saudi Arabia

Accepted for publication 12 January 1981
Riyadh, with particular reference to their epidemiology.

\section{Patients and methods}

ISOLATION AND IDENTIFICATION

Strains of $N$ gonorrhoeae were obtained from 83 patients (79 men and four women) with acute purulent gonococcal urethritis attending the dermatovenereological clinic, King Abdul Aziz $\frac{\circ}{\Phi}$ Teaching Hospital, Riyadh, between April 1979 and $\propto$ August 1980. Specimens of genital discharge were $\overrightarrow{\overrightarrow{0}}$ sent to the laboratory in a Stuart's transport medium and cultured on Thayer-Martin medium (Oxoid) and chocolate blood agar; the plates were incubated in candle extinction jars at $37^{\circ} \mathrm{C}$ for $24-48$ hours. Gonococci were identified by their morphological $\bar{c}$ characteristics, the oxidase reaction, and sugar fermentation tests.

\section{PENICILLIN SENSITIVITIES}

Doubling dilutions of penicillin $\mathrm{G}$ were incorporated in chocolate blood agar to give concentrations from $0.0075 \mu \mathrm{g} / \mathrm{ml}$ to $4 \mu \mathrm{g} / \mathrm{ml}$. A standard loop $(0.005 \mathrm{ml})$. was used to inoculate the plates with $10^{5}$ colony- $\sigma$ forming units (cfu). The inoculum was prepared by $N$ making a suspension of $N$ gonorrhoeae taken from $N$ an overnight culture on chocolate blood agar to 0 match a Browne's opacity tube number 4 , which is equivalent to $1.4 \times 10^{9}$ organisms $/ \mathrm{ml}$. The suspension was then diluted to give a final con- $\stackrel{0}{?}$ centration equivalent to $10^{5}$ organisms/inoculum. A 0 control chocolate blood agar plate without any ${ }^{\circ}$ antibiotic was included in each batch of tests and the Oxford strain of Staphylococcus aureus $(\mathrm{MIC}=0.03 \mu \mathrm{g} / \mathrm{ml}$ ) was used as control. 
B-LACTAMASE PRODUCTION

All strains of $N$ gonorrhoeae were tested for $\beta$-lactamase production by both intralactam strips and a plate method. The intralactam strips were obtained from Mast Laboratories (Liverpool, England), and tests were carried out according to the method of Whelden and Slack. ${ }^{16}$ In the plate method a chocolate agar plate was flooded with a suspension of the Oxford strain of Staph aureus, which is sensitive to ampicillin. When the plate was dry, an ampicillin disc $(10 \mu \mathrm{g})$ was placed in the centre of the plate and the test organism was streaked radially out from the disc. Known positive and negative controls were included on each plate. If $\beta$-lactamase is produced, the ampicillin will be denatured and the indicator Oxford Staph aureus will grow along the line of the streak up to the ampicillin disc.

\section{Results}

\section{PENICILLIN SENSITIVITIES}

The sensitivities to penicillin of 83 strains of $N$ gonorrhoeae are shown in the table. Ten (12\%) strains produced $\beta$-lactamase (MICs ranging from $1-4 \mu \mathrm{g} / \mathrm{ml}$ or greater). The $73(88 \%)$ strains which did not produce penicillinase (non-PPNG) were classified $^{17}$ as follows: $20(27 \%)$ were considered to be fully sensitive (MICs $=\leqslant 0.015 \mu \mathrm{g} / \mathrm{ml}$ ); $24(33 \%)$ had intermediate sensitivity (MICs ranging from 0.03 $\mu \mathrm{g} / \mathrm{ml}$ to $0.06 \mu \mathrm{g} / \mathrm{ml})$; and $29(40 \%)$ were relatively insensitive (MICs $=\geqslant 0 \cdot 12 \mu \mathrm{g} / \mathrm{ml})$.

\section{EPIDEMIOLOGY}

Most of the non-PPNG strains were probably acquired by the patients when in other countries, particularly other Middle-eastern countries, India, and South-east Asia. ${ }^{18}$

Six of the 10 patients infected with PPNG were Saudis and one an Indian. Six of the infections had been contracted abroad (Cairo, two; Bombay, two; Bangkok, one: and Morocco, one). One woman had been infected by her husband, who had acquired his infection in Bangkok. The place of infection of three patients was not known.

These patients infected with PPNG responded satisfactorily to treatment with gentamicin.

\section{Discussion}

Reports on the antibiotic resistance of strains of $N$ gonorrhoeae to penicillin started to appear in $1944 .^{19}$ Since then the impression of a progressive increase of resistance to penicillin has been confirmed. ${ }^{2}$ Fiftyfive per cent of our strains (excluding PPNG strains) showed diminished sensitivity to penicillin. This figure is comparable to those in Bombay $(56 \%)^{20}$ and Rotterdam $(48 \%)^{15}$ but is lower than those in Greenland $(86 \%),{ }^{21}$ Toronto $(80 \%),{ }^{22}$ Ethiopia $(66 \%),{ }^{23}$ USA $(70 \%),{ }^{24}$ and Nigeria $(82 \cdot 5 \%) .{ }^{25}$ The incidence of resistance may be high because antibiotics are easily available and are abused by the general public. Self-medication with inadequate doses and the frequent use of inappropriate antibiotics are common among prostitutes as well as among patients. Olsen and Lomholt ${ }^{21}$ showed that improving the results of treatment of gonorrhoea by increasing the dosage of penicillin lowers the prevalence of partially resistant strains.

In this study $10(12 \%)$ strains of $N$ gonorrhoeae were resistant to penicillin owing to $\beta$-lactamase production. This figure is higher than in other countries, for example, England (Liverpool) $9 \%{ }^{7}$ and the Netherlands $2-4 \% .1415$ It is, however, much lower than in some parts of the USA $(40 \%)^{10}$ and in Singapore $(53 \%) .^{11}$

We found that $15 \%$ of non-PPNG strains were highly resistant, with MICs for penicillin ranging from 0.5 to $2 \mu \mathrm{g} / \mathrm{ml}$. This confirms that two mechanisms may cause penicillin resistance in strains of $\mathbf{N}$ gonorrhoeae-namely, penicillinase production and some intrinsic interference in the passive diffusion of penicillin into the bacterial cell. Similar mechanisms of resistance were recently described in strains of Haemophilus influenzae. ${ }^{26}$

In one of our strains of PPNG a mixture of enzyme-negative and enzyme-positive colonies was found in the primary culture. This finding is similar to that of Percival et $a l^{7}$ who detected enzymenegative colonies in 1-30\% of colonies obtained from the primary clinical specimens. In addition, they pointed out that infections due to PPNG strains may be missed unless several anatomical sites are sampled since some patients harbour these strains in only some of the infected sites.

TABLE Minimum inhibitory concentrations of penicillin for 83 isolates of Neisseria gonorrhoeae

\begin{tabular}{|c|c|c|c|c|c|c|c|c|c|c|c|c|}
\hline \multirow[b]{2}{*}{ Strains } & \multicolumn{12}{|c|}{ No $(\%)$ of strains showing MICs $(\mu \mathrm{g} / \mathrm{ml})$ of: } \\
\hline & $0 \cdot 0075$ & 0.015 & 0.03 & 0.06 & $0 \cdot 12$ & $0 \cdot 25$ & 0.5 & $1 \cdot 0$ & $2 \cdot 0$ & $4 \cdot 0$ & $>4 \cdot 0$ & Total \\
\hline
\end{tabular}


It was not possible to detect the relative resistance to penicillin by a disc diffusion method. The MIC should, therefore, be routinely determined by a plate dilution technique in areas where the incidence of relative resistance is high and also in cases of treatment failure.

Because of the high prevalence of PPNG strains in Riyadh, we recommend that all gonococcal isolates should be screened for $\beta$-lactamase production, as stated by Sng et al. ${ }^{27}$ All strains should be screened firstly by a quick strip method; all positive and dubious results should then be confirmed by a plate or other methods.

\section{References}

1. Willcox RR. A survey of problems in the antibiotic treatment of gonorrhoea. With special reference to South-east Asia. Br J Vener Dis 1970; 46:217-42.

2. Willcox RR. A world-wide view of venereal diseases. $B r J$ Vener Dis 1972; 48: 163-76.

3. Anonymous. Penicillinase-producing gonococci. Lancet 1976; ii: 725-6.

4. Ashford WA, Golash RG, Hemming VG. Penicillinaseproducing Neisseria gonorrhoeae. Lancet 1976; ii:657-8.

5. Siegel MS, Thornsberry C, Biddle JW, O'Mara PR, Perine, PL, Wiesner PJ. Penicillinase-producing Neissera gonorrhoeae: results of surveillance in the United States. $J$ Infect Dis 1978; 137: 170-5.

6. Phillips I. $\beta$-lactamase-producing, penicillin-resistant gonococcus. Lancet 1976; ii: 656-7.

7. Percival A, Rowland J, Corkill JE et al. Penicillinaseproducing gonococci in Liverpool. Lancet 1976; ii: 1379-82.

8. Arya OP, Rees E, Percival A, Alergant CD, Annels EH, Turner GC. Epidemiology and treatment of gonorrhoea caused by penicillinase-producing strains in Liverpool. Br J Vener Dis 1978;54:28-35.

9. Hallet AF, Appelbaum PC, Cooper R, MokgoKong S, Monale D. Penicillinase-producing Neisseria gonorrhoeae from South Africa. Lancet 1977; i: 1205.
10. Berg SW, Kilpatrick ME, Harrison WO, McCutchan JA. Cefoxitin as a single-dose treatment for urethritis caused by penicillinase-producing strains of Neisseria gonorrhoeae. $N$ Engl J Med 1979; 301:509-11.

11. Rajan VS, Sng EH, Pang R, Tan NJ, Thirumoorthy $T$, Yeo KL. HR 756: A new cephalosporin, in the treatment of gonorrhoea caused by ordinary and penicillinase-producing strain of Neisseria gonorrhoeae. Br J Vener Dis 1980;56:255-8.

12. Wang FH. $\beta$-lactamase-producing gonococci in Hong Kong. $\mathrm{Br}$ $J$ Vener Dis 1980; 56: 270.

13. Grunder K, Petzoldt D. Sensitivity of Neisseria gonorrhoeae to spectinomycin and thiamphenicol. Br J Vener Dis 1980; 56:252-4.

14. Bijkerk $\mathrm{H}$. Penicillinase-producing gonococci in the Netherlands. Br J Vener Dis 1980;56:243-8.

15. Nayyar KC, Michel MF, Stolz E. Antibiotic sensitivities of gonococci isolated in Rotterdam and results of treatment with cefuroxime. Br J Vener Dis 1980;56:249-51.

16. Wheldon DB, Slack MPE. An evaluation of intralactam, a preparation for the detection of $\beta$-lactamase production by Haemophilus influenzae. J Clin Pathol 1979; 32:738-40.

17. Rodin P, Seth AD, King DM, Wilkinson AE. Sensitivity to penicillin of gonococci in different racial groups. Br J Vener Dis 1980; 56: 308-10.

18. Pareek SS, Chowdhury MNH. Sexually transmitted diseases in Riyadh, Saudi Arabia: a study of patients attending a teaching hospital. Br $J$ Vener Dis 1981, in press.

19. Reyn A, Kornor B, Bentzon MW. Effects of penicillin, streptomycin and tetracycline on $N$ gonorrhoeae isolated in 1944 and in 1957. Br $J$ Vener Dis 1958; 34:227-39.

20. Moses JM, Desai MS, Bhosle CB, Trasi MS. Present pattern of sensitivity of gonococcal strains isolated in Bombay. $\mathrm{Br} J$ Vener Dis 1971;47:273-8.

21. Olsen GA, Lomholt G. Gonorrhoea treated by a combination of probenecid and sodium penicillin G. $\mathrm{Br} J$ Vener Dis 1969; 45: 144-8.

22. Amies CR. Sensitivity of Neisseria gonorrhoeae to penicillin and other antibiotics. $B r J$ Vener Dis 1969; 45:216-22.

23. Plorde JJ, Kidan TG, Wright LJ. Penicillin sensitivity of gonococci in Ethiopia. Br J Vener Dis 1973;49:260-2.

24. Jaffe HW, Biddle JW, Thornsberry C et al. Gonorrhoea therapy monitoring: In-vitro antibiotic susceptibility and its correlation with treatment results. N Engl J Med 1976; 294:5-9.

25. Osoba AO, Montefiore DG, Sogbetun AO, Alausa KO, Anong CN. Sensitivity pattern of Neisseria gonorrhoeae to penicillin and screening for $\beta$-lactamase production in Ibadan, Nigeria. Br J Vener Dis 1977; 53:304-7.

26. Bell SM, Plowman D. Mechanism of ampicillin resistance in Haemophilus influenzae from the respiratory tract. Lancet 1980; i: $279-80$

27. Sng EH, Yeo KL, Rajan VS, Lim AL. Comparison of methods for the detection of penicillinase-producing Neisseria gonorrhoeae. Br J Vener Dis 1980;56:311-3. 